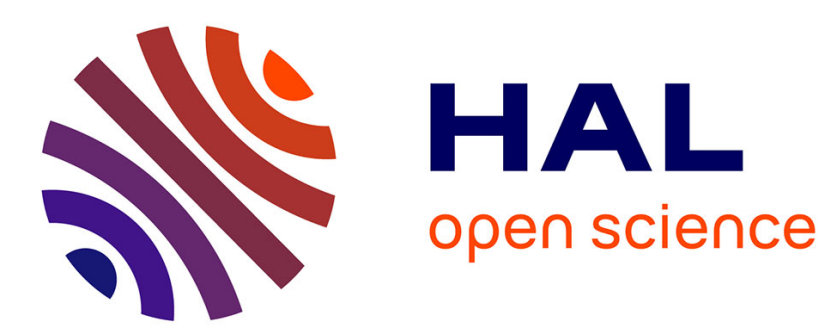

\title{
Hepatocellular Carcinoma and Statins
}

Ghazal Alipour Talesh, Véronique Trézéguet, Aksam Merched

\section{To cite this version:}

Ghazal Alipour Talesh, Véronique Trézéguet, Aksam Merched. Hepatocellular Carcinoma and Statins.

Biochemistry, 2020, 59 (37), pp.3393-3400. 10.1021/acs.biochem.0c00476 . hal-03373090

\section{HAL Id: hal-03373090 \\ https://hal.science/hal-03373090}

Submitted on 11 Oct 2021

HAL is a multi-disciplinary open access archive for the deposit and dissemination of scientific research documents, whether they are published or not. The documents may come from teaching and research institutions in France or abroad, or from public or private research centers.
L'archive ouverte pluridisciplinaire HAL, est destinée au dépôt et à la diffusion de documents scientifiques de niveau recherche, publiés ou non, émanant des établissements d'enseignement et de recherche français ou étrangers, des laboratoires publics ou privés. 


\title{
Hepatocellular Carcinoma and Statins
}

\author{
Ghazal Alipour Talesh ${ }^{1,2,3}$, Véronique Trézéguet ${ }^{*}$, Aksam Merched $^{1,4,5,{ }^{*}}$
}

${ }^{1}$ Université de Bordeaux, INSERM U1035, miRCaDe team, Biothérapie des Maladies Génétiques, Inflammatoires et du Cancer, Bordeaux 33076, France

${ }^{2}$ Storr Liver Centre, Westmead Institute for Medical Research, Westmead Hospital and University of Sydney, NSW 2145, Australia

${ }^{3}$ Present address: Murdoch Children's Research Institute, The Royal Children's Hospital, Parkville, Victoria, Australia

${ }^{4}$ Department of Molecular and Cellular Biology, Baylor College of Medicine, Houston, TX, USA

${ }^{5}$ Present address: Université de Bordeaux, INSERM U1035, miRCaDe team, Biothérapie des Maladies Génétiques, Inflammatoires et du Cancer, Bordeaux 33076, France

*Correspondence to: aksam.merched@u-bordeaux.fr, veronique.trezeguet-busquet@ubordeaux.fr

Keywords: HCC, Statins, Simvastatin, anti-tumour

\begin{abstract}
HMG-CoA reductase inhibitors (known as statins) are commonly prescribed worldwide for the management of coronary heart disease and the underlying dyslipidemia. This class of drugs
\end{abstract}


has been shown to infer significant decrease in the risk of cardiovascular morbidity and mortality. Only recently though, the potentially beneficial effects of statins in other diseases such as non-alcoholic steatohepatitis have been shown. Importantly also, multiple studies have revealed that statin use was associated with lower cancer-associated mortality across multiple types of cancers. This article aims at reviewing those studies with a particular focus on liver cancer. We also provide a review on the proposed mechanisms of actions describing how statins can induce chemo-preventive and anti-tumour effects. 


\begin{abstract}
ABBREVIATIONS
ASH, Alcoholic Steato-Hepatitis; cDDD, cumulative defined daily dose; CI, confidence interval; DEN, diethylnitrosamine; FDA, Food and Drug Administration; FPP, farnesylpyrophosphate; GGPP, geranylgeranyl pyrophosphate; HBV, hepatitis B virus; HCC, hepatocellular carcinoma; HCV, hepatitis C virus; HMG-CoA 3-hydroxy-3-methylglutaryl coenzyme A; Mcl-1, myeloid cell leukaemia-1; MVA, mevalonate ; NAFLD, non alcoolic fatty liver disease; NASH, non-alcoholic steatohepatitis; OR, odds ratio; SVR, standard variable rate; VEGF, vascular endothelial growth factor.
\end{abstract}


Introduction

Hepatocellular carcinoma (HCC) is the most common primary hepatic malignancy, accounting for more than $80 \%$ of primary liver tumours ${ }^{1,2}$. Globally, HCC is the fifth and seventh most frequent cancer in men and women, respectively ${ }^{1}$. HCC also represents the third and sixth leading cause of cancer-related mortality in men and women, respectively ${ }^{3}$. Given its dismal prognosis, HCC associated mortality rates are almost identical to the frequency of new cases $^{4}$. Liver cancer is normally diagnosed at an advanced stage, meaning that curative treatments (e.g., surgical resection, liver transplantation) may be applicable to only a small subset of patients ${ }^{5}$. Until recently, the only FDA approved first-line medications for HCC were sorafenib and regorafenib which increase the median survival merely by $10-12$ weeks ${ }^{6,7}$. During the last few years, immune checkpoint inhibitors such as nivolumab and pembrolizumab (PD-1 inhibitors) gained approval in in the second-line setting for patients with advanced HCC. On March 10, 2020, FDA granted accelerated approval to the combination of nivolumab and ipilimumab (a CTLA-4 inhibitor) as a second-line treatment of patients with HCC (FDA.org). The FDA approval was based on an early stage trial in which the objective response rate was $31 \%^{8}$. Given the lack of effective therapies for most patients and the fact that survival rates remain to be poor, there is an urgent unmet need to develop novel approaches to treatment.

Globally, HCC incidence continues to increase. Particularly, the incidence of HCC in developed countries with historically low rates such as the USA, Canada, Australia and Japan as well as Western Europe has been increasing markedly ${ }^{9,10}$. Indeed, the incidence of HCC in the USA alone has increased by approximately four fold over the past 40 years ${ }^{11}$. This is partially a result of the growing incidence of metabolic syndrome and steatohepatitis ${ }^{12,13}$.

Multiple pre-clinical and clinical studies have shown that therapies targeting diabetes or hyperlipidaemia might be effective in ameliorating type 2 diabetes- and non-alcoholic 
steatohepatitis (NASH)-related liver cancer $^{14,}{ }^{15}$. For instance, the lipid lowering agent ezetimibe that inhibits the intestinal absorption of cholesterol, was also shown to improve hepatic inflammation and steatosis but not fibrosis in NASH patients in 2 pilot clinical trials ${ }^{16}$, 17. Furthermore, statin use was found to be associated with protection from NASH, and fibrosis stage F2-F4, in a dose-dependent manner as reported in a clinical study including 107 patients ${ }^{18}$. Importantly also, multiple studies have revealed that statin use was associated with lower cancer-associated mortality across multiple types of cancers including HCC. This article aims at reviewing those studies with a particular focus on liver cancer. We then provide a review on the proposed mechanisms of action describing how statins can induce chemopreventive and anti-tumour effects.

\section{Statins in oncological research}

Statins are an important class of lipid lowering agents, acting through the inhibition of 3hydroxy-3-methylglutaryl coenzyme A (HMG-CoA) reductase, which is the rate-limiting enzyme of cholesterol biosynthesis. Statins are commonly prescribed for the treatment of hyperlipidaemia and cardiovascular diseases and have been associated with the primary and secondary prevention of heart attack and stroke. More recently though, other therapeutic effects of statins are beginning to unfold. In particular, they have been shown to be associated with lower cancer-associated mortality rates. For instance, a large population study on patients from the entire Danish population who were diagnosed with cancer between 1995 and 2007 revealed that the use of statins before diagnosis was associated with a significantly lower overall cancer related mortality ${ }^{19}$.

This is in tandem with in vitro and animal studies showing chemopreventive properties of statins mediated by their proapoptotic, antiangiogenic, antiproliferative (arresting of cell-cycle 
progression), immunomodulatory, metastasis inhibiting, and anti-infective effects and also possibly through targeting the cancer stem cell population ${ }^{20,21,22,23}$.

\section{Statins and Liver cancer}

Many studies have explored the association between statin use and the risk of liver cancersome of which will be reviewed in this section and also summarized in Table 1.

Table 1. Statin use and risk of liver cancer

\begin{tabular}{|c|c|c|c|c|}
\hline Statin & Initial pathology/setting & $\begin{array}{l}\text { Patients/animal } \\
\text { models }\end{array}$ & Effect on HCC risk & Reference \\
\hline Statins $^{(1)}$ & Steatosis & Patient cohort & $\begin{array}{l}48-91 \% \text { reduction of } \\
\text { HCC risk }\end{array}$ & $\begin{array}{l}\text { Dongiovanni } \\
\text { et al. }(2015)^{18}\end{array}$ \\
\hline Statins & NASH & Patient cohort & $\begin{array}{l}38-76 \% \text { reduction of } \\
\text { HCC risk }\end{array}$ & $\begin{array}{l}\text { Dongiovanni } \\
\text { et al. }(2015)^{18}\end{array}$ \\
\hline Statins & Fibrosis stage F2-F4 & Patient cohort & $\begin{array}{l}\sim 50 \% \text { reduction of } \\
\mathrm{HCC} \text { risk }\end{array}$ & $\begin{array}{l}\text { Dongiovanni } \\
\text { et al. }(2015)^{18}\end{array}$ \\
\hline Pitavastatin & Obesity and steatosis & $\begin{array}{l}\text { Male C57BL/KsJ- } \\
\mathrm{db} / \mathrm{db} \text { obese mice }\end{array}$ & $\begin{array}{l}\text { Inhibition of the } \\
\text { formation of hepatic } \\
\text { premalignant lesions }\end{array}$ & $\begin{array}{l}\text { Shimizu et al. } \\
(2011)^{24}\end{array}$ \\
\hline Pravastatin & $\begin{array}{l}\text { Advanced HCC treated } \\
\text { with transcatheter arterial } \\
\text { embolization \& oral 5- } \\
\text { FU with or without } \\
\text { Pravastatin }\end{array}$ & Patient cohort & $\begin{array}{l}\text { Extension of median } \\
\text { survival from } 9 \text { to } 18 \\
\text { months }\end{array}$ & $\begin{array}{l}\text { Kawata et al. } \\
(2001)^{25}\end{array}$ \\
\hline Pravastatin & $\begin{array}{l}\text { HCC treated with } \\
\text { chemoembolisation vs } \\
\text { chemobolisation }+ \\
\text { Pravastatin }\end{array}$ & Patient cohort & $\begin{array}{l}\text { Extension of median } \\
\text { survival from } 12 \text { to } \\
20.9 \text { months }\end{array}$ & $\begin{array}{l}\text { Graf et al. } \\
(2008)^{26}\end{array}$ \\
\hline Statins & Diabetes & Diabetic patients & $\begin{array}{l}\text { Marked reduction of } \\
\text { HCC risk }\end{array}$ & $\begin{array}{l}\text { El-Serag et } \\
\text { al. }(2009)^{27}\end{array}$ \\
\hline Statins & HBV & HBV patients & $\begin{array}{l}\text { Reduction of HCC } \\
\text { risk }\end{array}$ & $\begin{array}{l}\text { Tsan et al. } \\
(2012)^{28}\end{array}$ \\
\hline Statins & $\mathrm{HCV}$ & HCV patients & $\begin{array}{l}\text { Reduction of HCC } \\
\text { risk }\end{array}$ & $\begin{array}{l}\text { Tsan et al. } \\
(2013)^{29}\end{array}$ \\
\hline Statins & $\begin{array}{l}\text { Systematic review of five } \\
\text { case-control } \\
\text { observational studies }\end{array}$ & Meta-analysis & $\begin{array}{l}\text { Reduction of } \mathrm{HCC} \\
\text { risk particularly in } \\
\text { the case of } \\
\text { Atorvastatin (OR } \\
0.63,95 \% \text { CI } 0.45- \\
0.89 \text { ) and Fluvastatin } \\
\text { (OR } 0.58,95 \% \text { CI } \\
0.40-0.85 \text { ) }\end{array}$ & $\begin{array}{l}\text { Zhou et al. } \\
(2016)^{30}\end{array}$ \\
\hline
\end{tabular}




\begin{tabular}{|c|c|c|c|c|}
\hline Statins & Liver cancer & $\begin{array}{l}\text { Population- } \\
\text { based case-- } \\
\text { control study }\end{array}$ & $\begin{array}{l}\text { Reduction of liver } \\
\text { cancer risk at }<215.4 \\
\text { DDD * }\end{array}$ & $\begin{array}{l}\text { Chiu et al. } \\
(2011)^{21}\end{array}$ \\
\hline $\begin{array}{l}\text { Statins: } \\
\text { lipophilic } \\
\text { (atorvastatin, } \\
\text { simvastatin, } \\
\text { fluvastatin, } \\
\text { lovastatin) } \\
\text { vs. } \\
\text { hydrophilic } \\
\text { (pravastatin, } \\
\text { rosuvastatin) }\end{array}$ & HCC with viral hepatitis & $\begin{array}{l}\text { Cohort of patients } \\
\text { with confirmed } \\
\text { chronic HBV or } \\
\text { HCV infection in } \\
\text { Sweden. }\end{array}$ & $\begin{array}{l}\text { Significant } \\
\text { association of } \\
\text { lipophilic statins with } \\
\text { reduced HCC } \\
\text { incidence and } \\
\text { mortality, no } \\
\text { association with } \\
\text { hydrophilic statins }\end{array}$ & $\begin{array}{l}\text { Simon et al. } \\
(2011)^{31}\end{array}$ \\
\hline Statins & $\begin{array}{l}\text { Systematic review of } \\
\text { observational and } \\
\text { experimental studies }\end{array}$ & Meta-analysis & \begin{tabular}{|l|} 
Reduction risk of \\
HCC development
\end{tabular} & $\begin{array}{l}\text { Islam et al. } \\
(2020)^{32}\end{array}$ \\
\hline Statins & $\begin{array}{l}\text { Cholesterol Treatment } \\
\text { Trialists' (CTT) } \\
\text { Collaboration Study }\end{array}$ & Meta-analysis & $\begin{array}{l}\text { No reduction in the } \\
\text { incidence or } \\
\text { mortality rates }\end{array}$ & $\begin{array}{l}\text { Armitage et } \\
\text { al. }(2019)^{33}\end{array}$ \\
\hline Statins & Hyperlipidemia ** & $\begin{array}{l}\text { Population-based } \\
\text { cohort study }\end{array}$ & $\begin{array}{l}\text { No significant effect } \\
\text { on liver cancer } \\
\text { incidence }\end{array}$ & $\begin{array}{l}\text { Friis et al. } \\
(2005)^{34}\end{array}$ \\
\hline
\end{tabular}

(1) Where the name of the statin is not mentioned, there have been multiple statins involved. Please refer to the original article for the full list of statins used in each cohort.

A few studies have shown no connection between statin use and the overall risk of liver cancer. For instance, a meta-analysis of 28 randomised controlled trials including 186854 participants conducted by the Cholesterol Treatment Trialists' Collaboration showed that statin therapy had no effect at any age on cancer incidence or death ${ }^{33}$. On the other hand, multiple studies have described a significant decreased risk of developing HCC associated with the use of statins. For instance, in an experimental setting, pitavastatin was shown to reduce obesityand steatosis-mediated hepatocarcinogenesis in male $\mathrm{C} 57 \mathrm{BL} / \mathrm{Ks} J-\mathrm{db} / \mathrm{db}$ obese mice $^{24}$. A randomised controlled clinical trial with 83 patients revealed that pravastatin suppressed tumour growth and prolonged the survival of patients with advanced HCC (extending median survival from 9 to 18 months $)^{25}$. Furthermore, another report has demonstrated that a combined therapy of chemoembolisation plus pravastatin enhanced the survival of patients with advanced HCC versus those receiving only chemoembolization (with a median survival of 20.9 months 
vs. 12.0 months, respectively $)^{26}$. Multiple other studies have also reported a marked risk reduction for HCC with statin use in diabetic patients. For instance, a large, nested, matched, case-control study in patients with diabetes provided the first indication of a cancer-preventive effect for statins specific to HCC in this context $\mathrm{t}^{27}$. The study found a significant observed risk reduction ranging between $25 \%$ and $40 \%$.

As for virus-related HCC, a large HBV cohort of 328,946 person-years with the overall incidence rate of 310.4 HCCs per 100,000 person-years revealed a significant negative association between statin use and the risk of HCC in those patients ${ }^{28}$. The cumulative defined daily doses (cDDDs) of 28-83, 84-365, and greater than 365 have been associated with a 44\%, $53 \%$, and $67 \%$ risk reduction for $\mathrm{HCC}$, respectively, relative to no statin use reflecting a dosedependent effect. Similarly, a large HCV study revealed a similar pattern of a significant doseresponse relationship between statin use and HCC risk, reflecting the beneficial use of statins for the prevention of both HBV- and HBC- related $\mathrm{HCCs}{ }^{30}$.

Another comprehensive meta-analysis revealed that the use of statins (below 215.4 DDD) was associated with a $38 \%$ lower risk of liver cancer as compared with individuals who did not use statins ${ }^{21}$. Furthermore, a systematic review of five observational studies with a total of 87127 patients revealed that atorvastatin (OR $0.63,95 \%$ CI $0.45-0.89$ ) and fluvastatin (OR 0.58, $95 \%$ CI $0.40-0.85$ ) significantly dropped the risk of liver cancer ${ }^{30}$. In fact, the positive effect of statins in HCC patients has been observed in both Asian populations where chronic HBV was the underlying risk factor for $\mathrm{HCC}$ and also in Western populations with metabolic syndrome and NAFLD/NASH, as well as ASH (Alcoholic Steato-Hepatitis), being the major risk factors for developing $\mathrm{HCC}^{27}$. This may suggest that statins improving liver cancer survival may not necessarily be dependent on their lipid lowering function or their effect on metabolic syndrome or fatty liver disease. Alternatively, this may also underline the possibility that targeting the lipid metabolism of liver cancer cells could be a promising therapeutic approach effective of 
all types of HCC irrespective of the triggering conditions. In fact, it is well established that one of the most important metabolic hallmarks of cancer including HCC is the disruption of lipid metabolism in tumour cells. Indeed, HCC can represent the last stage of a liver disease where lipogenesis is enhanced, often resulting in the increase of free cholesterol. This aspect is reviewed more in detail by an accompanying review article by Alannan et al.

\section{Statins anti-tumour effects and mechanism of action}

While the mechanisms by which statins exert anti neoplastic effects are not fully elucidated yet, several reports have proposed multiple clues/hypotheses about the underlying molecular pathways that are often interconnected and will be briefly reviewed below and summarised in Figure 1 and Table 2.

Along with the inhibition of cholesterol biosynthesis, through the inhibition of HMG-CoA reductase and suppression of the conversion of HMG-CoA to mevalonate, statins inhibit the production of downstream products of the mevalonate pathway. Derivatives of the mevalonate pathway, primarily geranylgeranyl pyrophosphate (GGPP) and farnesylpyrophosphate (FPP) are necessary for post-translational prenylation and activation of various small $\mathrm{G}$ proteins, including small guanosine-5'-triphosphate binding proteins, such as Kras, and Rho family (discussed further by El-Serag et al. ${ }^{27}$ and Chiu et al. ${ }^{21}$ ). These proteins are important mediators of cell growth, differentiation, motility, signalling, membrane integrity, intracellular vesicle formation and trafficking as well as nucleo-cytoplasmic transport and survival. Statins thereby disrupt the crucial effects of these growth signalling proteins and can result in pro-apoptotic, anti-proliferative, anti-invasive and anti-angiogenic effect ${ }^{35}$. 


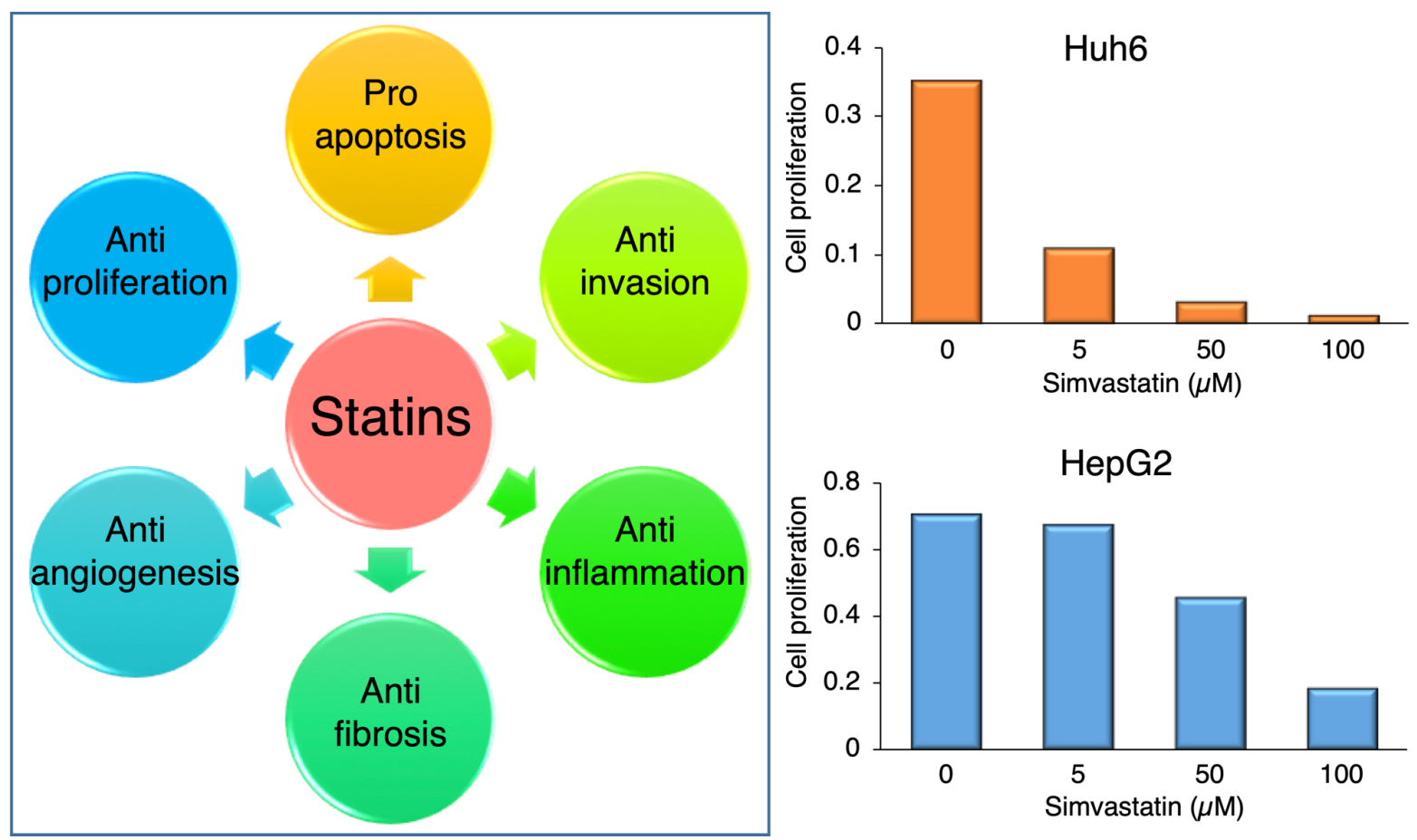

Figure 1. Potential mechanisms of action of statins in preventing hepatocellular carcinoma (see Table 2 for more details). Right graphs show dose dependent inhibition of liver cancer cell proliferation (Huh6 and HepG2) by simvastatin.

Table 2. Statins effects on cancer

\begin{tabular}{|l|l|l|l|}
\hline $\begin{array}{l}\text { Mechanism of } \\
\text { action }\end{array}$ & Statin & Effect & Reference \\
\hline $\begin{array}{l}\text { Inhibition of } \\
\text { proliferation }\end{array}$ & Cerivastatin & Blocking of Ras and Rhomediated cell growth & $\begin{array}{l}\text { Denoyelle } \text { et } \\
\text { al. }(2001)^{36}\end{array}$ \\
\cline { 2 - 5 } & Lovastatin & $\begin{array}{l}\text { Inhibition of the activation of the proteasome } \\
\text { pathway, leading to p21 and p27 stabilisation }\end{array}$ & $\begin{array}{l}\text { Rao } \text { et al. } \\
(1999)^{37}\end{array}$ \\
\cline { 2 - 5 } & Lovastatin & $\begin{array}{l}\text { Cell cycle arrest by blocking of G1/S and } \\
\text { G2/M transition }\end{array}$ & $\begin{array}{l}\text { Naderi } \text { et al. } \\
(1999)^{38}\end{array}$ \\
\cline { 2 - 5 } & $\begin{array}{l}\text { Simvastatin } \\
\text { and lovastatin }\end{array}$ & $\begin{array}{l}\text { Inhibition of the proliferation and collagen } \\
\text { steady state levels in hepatic stellate cells }\end{array}$ & $\begin{array}{l}\text { Rombouts } \text { et } \\
\text { al. }(2003)^{39}\end{array}$ \\
\hline \multirow{2}{*}{$\begin{array}{l}\text { Induction of } \\
\text { apoptosis }\end{array}$} & $\begin{array}{l}\text { Fluva, Simva } \\
\text { and Lovastatin }\end{array}$ & $\begin{array}{l}\text { Downregulation of the MVA pathway and } \\
\text { inhibition of prenylation of small G proteins }\end{array}$ & $\begin{array}{l}\text { Kah } \text { et al. } \\
(2012)^{40}\end{array}$ \\
\cline { 2 - 4 }
\end{tabular}




\begin{tabular}{|c|c|c|c|}
\hline & Simvastatin & $\begin{array}{l}\text { Non canonical regulation of RhoA and Rac1 } \\
\text { GTPases through the downstream } \\
\text { superoxidemediated activation of JNK } \\
\text { pathway }\end{array}$ & $\begin{array}{l}\text { Zhu et al. } \\
(2013)^{41}\end{array}$ \\
\hline & Lovastatin & $\begin{array}{l}\text { Caspase activation; BCL-2 inhibition and Bax } \\
\text { upregulation (regulation of MEKERK } \\
\text { pathway) }\end{array}$ & $\begin{array}{l}\text { Marcelli et } \\
\text { al. }(1998)^{42} \\
\text { Wu et al. } \\
(2004)^{43}\end{array}$ \\
\hline & Atorvastatin & $\begin{array}{l}\text { Activation of caspase } 9 \text { and caspase } 3 \text { (in } \\
\text { hepatic stellate cells) }\end{array}$ & $\begin{array}{l}\text { Aprigliano et } \\
\text { al. }(2008)^{44}\end{array}$ \\
\hline & Simvastatin & $\begin{array}{l}\text { Activation of Bax and downregulation of } \\
\text { BCL-2 }\end{array}$ & $\begin{array}{l}\text { Spampanato } \\
\text { et al. } \\
(2012)^{45}\end{array}$ \\
\hline & $\begin{array}{l}\text { Fluvastatin }+ \\
\text { celecoxib }\end{array}$ & $\begin{array}{l}\text { Upregulation of cyclindependent kinase } \\
\text { inhibitor p21(Waf1/Cip1), downregulation of } \\
\text { pAkt, myeloid cell leukaemial (Mcl1) and } \\
\text { survivin proteins }\end{array}$ & $\begin{array}{l}\text { Gao et al. } \\
(2010)^{46}\end{array}$ \\
\hline \multirow{4}{*}{$\begin{array}{l}\text { Impact on the } \\
\text { adhesive } \\
\text { capacity, } \\
\text { angiogenesis and } \\
\text { invasion of } \\
\text { tumour cells }\end{array}$} & $\begin{array}{l}\text { Cerivastatin } \\
\text { and } \\
\text { atorvastatin }\end{array}$ & $\begin{array}{l}\text { Biphasic dose dependent effect:proangiogenic } \\
\text { effect at low concentrations; antiangiogenic } \\
\text { effect at higher concentrations }\end{array}$ & $\begin{array}{l}\text { Weis et al. } \\
(2002)^{47}\end{array}$ \\
\hline & Atorvastatin & Inhibition of angiogenesis and migration & $\begin{array}{l}\text { Bayat et al. } \\
(2018)^{48}\end{array}$ \\
\hline & Simvastatin & $\begin{array}{l}\text { Inhibition of capillary formation (by blocking } \\
\text { vascular endothelial growth factor (VEGF), } \\
\text { Akt, and focal adhesion kinase signalling } \\
\text { (FAK)) }\end{array}$ & $\begin{array}{l}\text { Park et al. } \\
(2002)^{49}\end{array}$ \\
\hline & Simvastatin & $\begin{array}{l}\text { Inhibition of tumour cell growth, attachment } \\
\text { to endothelium and invasion (in HCC cell } \\
\text { lines) }\end{array}$ & $\begin{array}{l}\text { Relja et al. } \\
(2011)^{50}\end{array}$ \\
\hline $\begin{array}{l}\text { Impact on } \mathrm{HCV} \\
\text { pathogenesis }\end{array}$ & Lovastatin & $\begin{array}{l}\text { Reduction of geranylgeranyl pyrophosphate, } \\
\text { leading to the disruption of HCVRNA } \\
\text { replication and reduction of viral load }\end{array}$ & $\begin{array}{l}\text { Ye et al. } \\
(2003)^{51}\end{array}$ \\
\hline $\begin{array}{l}\text { Suppression of } \\
\text { the proliferation } \\
\text { of embryonic } \\
\text { stem cells }\end{array}$ & Simvastatin & $\begin{array}{l}\text { Selectively blocking cytosoltomembrane } \\
\text { translocalisation of RhoA small guanosine } \\
\text { triphosphatebinding protein, decreasing } \\
\text { Rhokinase (ROCK)2, downregulating ROCK } \\
\text { activity }\end{array}$ & $\begin{array}{l}\text { Lee et al. } \\
(2007)^{52}\end{array}$ \\
\hline $\begin{array}{l}\text { Inhibition of } \\
\text { Myc } \\
\text { phosphorylation } \\
\text { and activation }\end{array}$ & Atorvastatin & $\begin{array}{l}\text { Suppression of tumour initiation and growth } \\
\text { transgenic in a model of Mycinduced HCC }\end{array}$ & $\begin{array}{l}\text { Cao et al. } \\
(2011)^{53}\end{array}$ \\
\hline
\end{tabular}




\section{Inhibition of proliferation}

Through the inhibition of HMG-CoA reductase and subsequent to the reduction of isoprenoids, statins can inhibit the proliferation of cancer cells. Particularly, cerivastatin has been shown to block Ras- and Rho-mediated cell growth ${ }^{22,23}$.

The inhibition of cell proliferation by statins is not necessarily dependent on Ras function; Lovastatin was proposed to inhibit the activation of the proteasome pathway, resulting in p21 and p27 (both major cyclin-dependent kinase inhibitors that can hinder the growth of cancerous cells) stabilisation. Statins thereby can enhance the effect of these molecules in proliferation inhibition and retarding cancer cell mitosis ${ }^{37}$.

Another study has also demonstrated that simvastatin and lovastatin inhibited the proliferation of hepatic stellate cells and their collagen steady state levels in a dose dependent manner ${ }^{39}$. Pravastatin (10-20 mg/kg every other day) was shown to be associated with a lower risk of neoplastic hepatic nodules formation in a model of $\mathrm{N}$-nitrosomorpholine induced hepatocarcinogenesis in sprague-dawley rats $^{54}$ and this was suggested to be due to the inhibition of p21ras isoprenylation and the subsequent inhibition of cell proliferation and induction of apoptosis in neoplastic lesions. Furthermore, lovastatin has been shown to induce cell cycle arrest by blocking G1/S and G2/M transition without the signs of apoptosis ${ }^{38}$, projecting that statin-induced proliferation inhibition is not only dependent on its apoptosis inducing effects.

\section{Induction of apoptosis}

One of the mechanisms proposed for tumour suppressing effect of statins is the induction/deregulation of apoptosis. Statin mediated apoptosis is predominantly through downregulation of the mevalonate (MVA) pathway and the depletion of geranylgeranylated proteins. Kah et al. (2012), have demonstrated that the anti-tumour effect of statins was not 
dependent on the inhibition of cholesterol production, but was based on the inhibition of prenylation, since restoration of mevalonate or geranyl-geranylation reversed the statin cytotoxicity in vitro ${ }^{40}$. Statin-mediated depletion of mevalonate pathway product-modified proteins and its proapoptotic effect were suggested to involve non-canonical regulation of one the most important geranylgeranylated proteins, Rho GTPases and to be mediated through the downstream superoxide-mediated activation of JNK pathway ${ }^{41}$.

There are also other mechanisms suggested for the pro-apoptotic effects of statins. Through HMG-CoA reductase inhibition and by activating caspases critically involved in apoptosis, as well as the inhibition of the antiapoptotic protein Bcl-2, combined with the upregulation of the proapoptotic protein Bax, lovastatin was shown to regulate $\mathrm{RAF} /$ mitogen-activated protein kinase 1/extracellular signal-regulated kinase (MEK-ERK) pathway and thereby induce proapoptotic functions $s^{42,43}$. Furthermore, atorvastatin was shown to significantly increase the protease activity of caspase- 9 and caspase- 3 and induce apoptosis in activated hepatic stellate cells $^{44}$. Spampanato C. et al., demonstrated that simvastatin, (at $20 \mu \mathrm{M}$ for $24-72 \mathrm{~h}$ ) induced the expression of Bax and inhibited Bcl-2 expression in several cancer cell lines (including breast cancer, gastric cancer and hepatic carcinoma), leading to enhanced DNA fragmentation. Interestingly, statin-mediated apoptosis was observed only in the cancer cells and the noncancerous fibroblasts did not show any sign of apoptosis, even after 3 days of exposure to the drug $^{45}$. This reflects promising indications for statins in cancer. Both Bax and Bcl-2 are transcriptional targets for the tumour suppressor protein p53 which plays an important role in cell cycle arrest and apoptosis in response to DNA damage ${ }^{45,55}$. It has been shown that the antitumour activity of statins requires cell proliferation and is reduced by p53 overexpression. Indeed, the p53 over-expressing human hepatoma cell line Huh7 could be sensitised towards statin-mediated apoptosis by stable knockdown of endogenous p53 ${ }^{40}$. However, p53independent mitochondrial-mediated apoptosis has also been reported following lovastatin 
exposure in a mouse mammary carcinoma ${ }^{56}$. These indicate the complexity of statins molecular mechanism of action which reflects the need for further elucidation.

\section{Impact on the adhesive capacity, angiogenesis and invasion of tumour cells}

Endothelial cell migration and proliferation play a critical role in angiogenesis. Several studies have previously shown that statins inhibit cell migration ${ }^{57}$.

It has been shown that cerivastatin and atorvastatin have a biphasic dose dependent effect on angiogenesis, with probably a pro-angiogenic effect at low concentrations $0.005-<0.05$ $\mu \mathrm{mol} / \mathrm{L}$ (in vitro) or $0.5 \mathrm{mg} \cdot \mathrm{kg}-1 \cdot \mathrm{d}-1$ (in vivo) and an anti-angiogenic effect at higher concentrations $\geq 0.05 \mu \mathrm{mol} / \mathrm{L}$ (in vitro) or $2.5 \mathrm{mg} / \mathrm{kg}$.d (in vivo) as shown in vitro (human dermal microvascular endothelial cells) and in vivo (a murine Lewis lung cancer model) $)^{47}$. More recently, atorvastatin was demonstrated to inhibit angiogenesis and migration in an in vitro glioblastoma model in a dose dependent manner (studied in 1 to $10 \mu \mathrm{M}$ concentrations) $)^{48}$. Satins were also suggested to inhibit capillary formation by blocking vascular endothelial growth factor (VEGF), Akt, and focal adhesion kinase signalling (FAK)- which are RhoAdependent pathways crucially involved in angiogenesis ${ }^{49}$.

Overall, statins have been shown to impair the metastatic potential of tumour cells by inhibiting cell migration, adhesion to the extracellular matrix, and invasion of the basement membrane as observed in several cancer cell lines. However, only few studies have investigated this in the context of HCC. Relja et al., $(2011)^{50}$ have demonstrated that simvastatin dose-dependently decreased tumour cell growth and impaired tumour cell adhesion to endothelial cell monolayers leading to reduced tumour cell invasion ${ }^{50}$. The latter was associated with decreased expression of $\mathrm{b} 1, \mathrm{~b} 3$ and $\mathrm{a} 2$ integrins and was reversed by exogenous mevalonate ${ }^{50}$. 


\section{Impact on HCV pathogenesis}

Statins are suggested to play a crucial role in the prognosis of HCV infection, which is currently a major risk factor for HCC and cirrhosis across the globe.

Statins have an anti-infective effect specific to $\mathrm{HCV}$, the replication of which is believed to be at least partially dependent on geranylgeranylation of a host protein. High doses of statins can cause depletion of mevalonic acid, and consequently a reduction of cellular levels of the substrate for the geranylgeranyl-transferase, geranylgeranyl pyrophosphate. The decrease in geranylgeranyl pyrophosphate can lead to the disruption of HCV-RNA replication and therefore the reduction of the viral load and improvement of SVR in some patients ${ }^{51,58}$. In this regard, statins are suggested to improve the response to treatment with interferon- $\alpha$ plus ribavirin ${ }^{59}$. Furthermore, the protective effect of statins in this population may be mediated through the amelioration of metabolic disturbances, as well as counteracting the HCVmediated immune activation, inflammation, proliferation, and cell growth. As a result of these effects, statins could have a long term benefit for HCV patients by retarding the progression of liver fibrosis, and decreasing the risk of $\mathrm{HCC}$ incidence and cirrhosis ${ }^{60,61}$.

\section{Other mechanisms of action}

There are also other mechanisms that were proposed to be involved in the anti-tumour function of statins but these are less explored. These include anti-inflammatory and immunomodulatory effects, inhibition of cancer stem cells and Myc inhibition among others.

Statins were suggested to hinder the cell cycle inhibitor p27Kip1 and thereby enhance the proliferation of different types of stem cells, including endothelial progenitor cells ${ }^{62}$. On the other hand, another study has shown that through the inhibition of RhoA/ROCK-dependent cell-signalling, statins suppressed the proliferation of embryonic stem cells ${ }^{52}$. 
In both human HCC-derived cell lines and a transgenic model of Myc-induced HCC, atorvastatin was demonstrated to inhibit Myc phosphorylation and activation, and to suppress tumour initiation and growth via HMG-CoA reductase-dependent pathway ${ }^{53}$. Indeed, Myc activation is a critical step in hepatocarcinogenesis, and its inactivation has been shown to induce sustained regression of $\mathrm{HCC}^{63}$.

Furthermore, statins are reported to have synergistic anti-tumour effects with cyclooxygenase- 2 inhibitors ${ }^{64}$. In a HCC mouse model, the combination of celecoxib and fluvastatin enhanced the level of cyclin-dependent kinase inhibitor p21(Waf1/Cip1), reduced p-Akt, myeloid cell leukaemia-1 (Mcl-1) and survivin proteins. This combination thereby increased the rate of apoptosis and enhanced the inhibition of tumour growth, tumour cell proliferation, and tumour angiogenesis compared with either of the treatments alone ${ }^{46}$.

\section{Statins side effects}

In spite of being widely prescribed to lower blood cholesterol levels, discontinuation of treatment with statins may be advised in case of the development of several forms of toxicities and/or intolerance ${ }^{65}$. Nonetheless, there is no universal agreement on the definition of statin toxicity or intolerance. This being said, the most frequently reported side effects are statinassociated muscle related side effects, accounting for up to $72 \%$ of all statin related adverse events $^{66}$. Other commonly reported side effects include the new-onset type 2 diabetes mellitus, and to a lesser extent, the neurological and neurocognitive manifestations, hepatotoxicity, renal toxicity, and others.

Although the mechanisms of all these toxicities are varied and linked to multiple pathways, the end result is a change in drug bioavailability and activity in different tissues. The fact that toxic myopathy is a more common condition associated with statin use, while myocardium is spared from its side-effects, may be related to tissue-specific pleiotropic effects of statins. This 
is particularly relevant as some transporters of statins are expressed in skeletal muscles but are absent in cardiomyocytes ${ }^{67}$.

As for hepatotoxicity, statins are considered a relatively hepato-safe class of drugs. However, there are reports showing that they can occasionally cause elevations in liver function tests in some patients. For instance, treatment with high doses of atorvastatin or simvastatin (80 $\mathrm{mg} /$ day) was associated with an increased risk of liver function test abnormalities ${ }^{68}$. On the other hand, another study has shown that low-to-moderate doses of pravastatin, lovastatin, and simvastatin were not associated with a significant risk for abnormalities on liver function testing ${ }^{69}$.

The molecular mechanisms underlying statin toxicities/intolerance remain poorly understood. Regardless, there is an urgent need to identify those at higher risk of developing side effects and to provide them with an adapted clinical management/treatment regimen.

\section{Future perspectives}

Statins are the bedrock of all international guidelines on hyperlipidaemia management and their role in the reduction of the risk of cardiovascular events in a range of patient with atherosclerotic cardiovascular diseases, diabetes mellitus, and hyperlipidaemia has been widely established.

Strong evidence from several observational studies and experimental studies support the benefits of statin use in chemoprevention, slowing the growth rate of $\mathrm{HCC}$ and increasing $\mathrm{HCC}$ patients' survival and thereby indicate the preventive and therapeutic potential of statins in this context.

Although several international organisations have identified statin side effects to be of major clinical importance, that may be outweighed by statins beneficial effects particularly in the context of a poor prognosis cancer. Similarly, the use of statins in NASH patients may also be 
justified as they help improve hyperlipidaemia and metabolic syndrome which are commonly associated with $\mathrm{NASH}^{70}$. Nevertheless, in case of the application of high doses, potential side effects have to be closely monitored.

Whilst a higher cumulative dose of statins is expected to have a higher chemopreventive effect than low doses ${ }^{20}$, detailed data on the most effective statin type as well as the most compelling duration and dosage are lacking. More prospective interventional studies and comprehensive randomised controlled trials are therefore needed to confirm the effect of statins in the chemoprevention of HCC.

Finally, since one of the most important metabolic hallmarks of liver tumour cells is an enhanced overall lipogenesis, combining statins with other lipid metabolism inhibitors may emerge as a more effective therapeutic approach for liver cancer (see accompanying review by Alannan et al.).

Acknowledgements:

This work was supported by the Association les Récoltes de l'Espoir, the Institut National de la Santé et de la Recherche Médicale-INSERM, the Centre National de la Recherche Scientifique-CNRS, and the University of Bordeaux. GAT was a recipient of the University of Sydney Vice Chancellor Global Mobility Scholarship.

\section{References}

(1) El-Serag, H. B. (2011) Hepatocellular carcinoma. N. Engl. J. Med. 365, 1118-1127.

(2) Llovet, J. M., Peña, C. E. A., Lathia, C. D., Shan, M., Meinhardt, G., Bruix, J., and SHARP Investigators Study Group. (2012) Plasma biomarkers as predictors of outcome in patients with advanced hepatocellular carcinoma. Clin. Cancer Res. 18, 2290-2300. 
(3) Nordenstedt, H., White, D. L., and El-Serag, H. B. (2010) The changing pattern of epidemiology in hepatocellular carcinoma. Dig Liver Dis 42 Suppl 3, S206-214.

(4) Ferlay, J., Shin, H.-R., Bray, F., Forman, D., Mathers, C., and Parkin, D. M. (2010) Estimates of worldwide burden of cancer in 2008: GLOBOCAN 2008. Int. J. Cancer 127, $2893-2917$.

(5) Clark, T., Maximin, S., Meier, J., Pokharel, S., and Bhargava, P. (2015) Hepatocellular Carcinoma: Review of Epidemiology, Screening, Imaging Diagnosis, Response Assessment, and Treatment. Curr Probl Diagn Radiol 44, 479-486.

(6) Llovet, J. M., Ricci, S., Mazzaferro, V., Hilgard, P., Gane, E., Blanc, J.-F., de Oliveira, A. C., Santoro, A., Raoul, J.-L., Forner, A., Schwartz, M., Porta, C., Zeuzem, S., Bolondi, L., Greten, T. F., Galle, P. R., Seitz, J.-F., Borbath, I., Häussinger, D., Giannaris, T., Shan, M., Moscovici, M., Voliotis, D., Bruix, J., and SHARP Investigators Study Group. (2008) Sorafenib in advanced hepatocellular carcinoma. N. Engl. J. Med. 359, 378-390.

(7) Ringelhan, M., Pfister, D., O’Connor, T., Pikarsky, E., and Heikenwalder, M. (2018) The immunology of hepatocellular carcinoma. Nat. Immunol. 19, 222-232.

(8) Yau, T., Kang, Y.-K., Kim, T.-Y., El-Khoueiry, A. B., Santoro, A., Sangro, B., Melero, I., Kudo, M., Hou, M.-M., Matilla, A., Tovoli, F., Knox, J. J., He, A. R., El-Rayes, B. F., Acosta-Rivera, M., Neely, J., Shen, Y., Baccan, C., Dela Cruz, C. M., and Hsu, C. (2019) Nivolumab (NIVO) + ipilimumab (IPI) combination therapy in patients (pts) with advanced hepatocellular carcinoma (aHCC): Results from CheckMate 040. JCO 37, 4012-4012.

(9) Bosch, F. X., Ribes, J., Díaz, M., and Cléries, R. (2004) Primary liver cancer: worldwide incidence and trends. Gastroenterology 127, S5-S16. 
(10) El-Serag, H. B., and Mason, A. C. (1999) Rising incidence of hepatocellular carcinoma in the United States. N. Engl. J. Med.340, 745-750.

(11) Massarweh, N. N., and El-Serag, H. B. (2017) Epidemiology of Hepatocellular Carcinoma and Intrahepatic Cholangiocarcinoma. Cancer Control 24, 1073274817729245.

(12) Wong, V. W.-S., Chitturi, S., Wong, G. L.-H., Yu, J., Chan, H. L.-Y., and Farrell, G. C. (2016) Pathogenesis and novel treatment options for non-alcoholic steatohepatitis. Lancet Gastroenterol Hepatol 1, 56-67.

(13) Loomba, R., and Sanyal, A. J. (2013) The global NAFLD epidemic. Nat Rev Gastroenterol Hepatol 10, 686-690.

(14) Obara, K., Shirakami, Y., Maruta, A., Ideta, T., Miyazaki, T., Kochi, T., Sakai, H., Tanaka, T., Seishima, M., and Shimizu, M. (2017) Preventive effects of the sodium glucose cotransporter 2 inhibitor tofogliflozin on diethylnitrosamine-induced liver tumorigenesis in obese and diabetic mice. Oncotarget 8, 58353-58363.

(15) Zhang, Z.-J., Zheng, Z.-J., Shi, R., Su, Q., Jiang, Q., and Kip, K. E. (2012) Metformin for liver cancer prevention in patients with type 2 diabetes: a systematic review and metaanalysis. J. Clin. Endocrinol. Metab. 97, 2347-2353.

(16) Yoneda, M., Fujita, K., Nozaki, Y., Endo, H., Takahashi, H., Hosono, K., Suzuki, K., Mawatari, H., Kirikoshi, H., Inamori, M., Saito, S., Iwasaki, T., Terauchi, Y., Kubota, K., Maeyama, S., and Nakajima, A. (2010) Efficacy of ezetimibe for the treatment of non-alcoholic steatohepatitis: An open-label, pilot study. Hepatol. Res. 40, 566-573.

(17) Park, H., Shima, T., Yamaguchi, K., Mitsuyoshi, H., Minami, M., Yasui, K., Itoh, Y., Yoshikawa, T., Fukui, M., Hasegawa, G., Nakamura, N., Ohta, M., Obayashi, H., and 
Okanoue, T. (2011) Efficacy of long-term ezetimibe therapy in patients with nonalcoholic fatty liver disease. J. Gastroenterol. 46, 101-107.

(18) Dongiovanni, P., Petta, S., Mannisto, V., Mancina, R. M., Pipitone, R., Karja, V., Maggioni, M., Kakela, P., Wiklund, O., Mozzi, E., Grimaudo, S., Kaminska, D., Rametta, R., Craxi, A., Fargion, S., Nobili, V., Romeo, S., Pihlajamaki, J., and Valenti, L. (2015) Statin use and non-alcoholic steatohepatitis in at risk individuals. J. Hepatol. 63, 705-712.

(19) Nielsen, S. F., Nordestgaard, B. G., and Bojesen, S. E. (2013) Statin use and reduced cancer-related mortality. N. Engl. J. Med. 368, 576-577.

(20) Singh, S., Singh, P. P., Singh, A. G., Murad, M. H., and Sanchez, W. (2013) Statins are associated with a reduced risk of hepatocellular cancer: a systematic review and meta-analysis. Gastroenterology 144, 323-332.

(21) Chiu, H.-F., Ho, S.-C., Chen, C.-C., and Yang, C.-Y. (2011) Statin use and the risk of liver cancer: a population-based case-control study. Am. J. Gastroenterol. 106, 894-898.

(22) Demierre, M.-F., Higgins, P. D. R., Gruber, S. B., Hawk, E., and Lippman, S. M. (2005) Statins and cancer prevention. Nat. Rev. Cancer 5, 930-942.

(23) Sassano, A., Katsoulidis, E., Antico, G., Altman, J. K., Redig, A. J., Minucci, S., Tallman, M. S., and Platanias, L. C. (2007) Suppressive effects of statins on acute promyelocytic leukemia cells. Cancer Res. 67, 4524-4532.

(24) Shimizu, M., Yasuda, Y., Sakai, H., Kubota, M., Terakura, D., Baba, A., Ohno, T., Kochi, T., Tsurumi, H., Tanaka, T., and Moriwaki, H. (2011) Pitavastatin suppresses diethylnitrosamine-induced liver preneoplasms in male $\mathrm{C} 57 \mathrm{BL} / \mathrm{KsJ}-\mathrm{db} / \mathrm{db}$ obese mice. $B M C$ Cancer 11, 281. 
(25) Kawata, S., Yamasaki, E., Nagase, T., Inui, Y., Ito, N., Matsuda, Y., Inada, M., Tamura, S., Noda, S., Imai, Y., and Matsuzawa, Y. (2001) Effect of pravastatin on survival in patients with advanced hepatocellular carcinoma. A randomized controlled trial. Br. J. Cancer 84, 886891.

(26) Graf, H., Jüngst, C., Straub, G., Dogan, S., Hoffmann, R.-T., Jakobs, T., Reiser, M., Waggershauser, T., Helmberger, T., Walter, A., Walli, A., Seidel, D., Goke, B., and Jüngst, D. (2008) Chemoembolization combined with pravastatin improves survival in patients with hepatocellular carcinoma. Digestion 78, 34-38.

(27) El-Serag, H. B., Johnson, M. L., Hachem, C., and Morgana, R. O. (2009) Statins Are Associated With a Reduced Risk of Hepatocellular Carcinoma in a Large Cohort of Patients With Diabetes. Gastroenterology 136, 1601-1608.

(28) Tsan, Y.-T., Lee, C.-H., Wang, J.-D., and Chen, P.-C. (2012) Statins and the risk of hepatocellular carcinoma in patients with hepatitis B virus infection. J. Clin. Oncol. 30, 623630.

(29) Tsan, Y.-T., Lee, C.-H., Ho, W.-C., Lin, M.-H., Wang, J.-D., and Chen, P.-C. (2013) Statins and the risk of hepatocellular carcinoma in patients with hepatitis $\mathrm{C}$ virus infection. $J$. Clin. Oncol.31, 1514-1521.

(30) Zhou, Y.-Y., Zhu, G.-Q., Wang, Y., Zheng, J.-N., Ruan, L.-Y., Cheng, Z., Hu, B., Fu, S.-W., and Zheng, M.-H. (2016) Systematic review with network meta-analysis: statins and risk of hepatocellular carcinoma. Oncotarget 7, 21753-21762.

(31) Simon, T. G., Duberg, A.-S., Aleman, S., Hagstrom, H., Nguyen, L. H., Khalili, H., Chung, R. T., and Ludvigsson, J. F. (2019) Lipophilic Statins and Risk for Hepatocellular 
Carcinoma and Death in Patients With Chronic Viral Hepatitis: Results From a Nationwide Swedish Population. Ann. Intern. Med. 171, 318-327.

(32) Islam, M. M., Poly, T. N., Walther, B. A., Yang, H.-C., and Jack Li, Y.-C. (2020) Statin Use and the Risk of Hepatocellular Carcinoma: A Meta-Analysis of Observational Studies. Cancers (Basel) 12.

(33) Cholesterol Treatment Trialists' Collaboration. (2019) Efficacy and safety of statin therapy in older people: a meta-analysis of individual participant data from 28 randomised controlled trials. Lancet 393, 407-415.

(34) Friis, S., Poulsen, A. H., Johnsen, S. P., McLaughlin, J. K., Fryzek, J. P., Dalton, S. O., Sørensen, H. T., and Olsen, J. H. (2005) Cancer risk among statin users: a population-based cohort study. Int. J. Cancer 114, 643-647.

(35) Konstantinopoulos, P. A., Karamouzis, M. V., and Papavassiliou, A. G. (2007) Posttranslational modifications and regulation of the RAS superfamily of GTPases as anticancer targets. Nat Rev Drug Discov 6, 541-555.

(36) Denoyelle, C., Vasse, M., Körner, M., Mishal, Z., Ganné, F., Vannier, J. P., Soria, J., and Soria, C. (2001) Cerivastatin, an inhibitor of HMG-CoA reductase, inhibits the signaling pathways involved in the invasiveness and metastatic properties of highly invasive breast cancer cell lines: an in vitro study. Carcinogenesis 22, 1139-1148.

(37) Rao, S., Porter, D. C., Chen, X., Herliczek, T., Lowe, M., and Keyomarsi, K. (1999) Lovastatin-mediated G1 arrest is through inhibition of the proteasome, independent of hydroxymethyl glutaryl-CoA reductase. Proc. Natl. Acad. Sci. U.S.A. 96, 7797-7802. 
(38) Naderi, S., Blomhoff, R., Myklebust, J., Smeland, E. B., Erikstein, B., Norum, K. R., and Blomhoff, H. K. (1999) Lovastatin inhibits G1/S transition of normal human Blymphocytes independent of apoptosis. Exp. Cell Res. 252, 144-153.

(39) Rombouts, K., Kisanga, E., Hellemans, K., Wielant, A., Schuppan, D., and Geerts, A. (2003) Effect of HMG-CoA reductase inhibitors on proliferation and protein synthesis by rat hepatic stellate cells. J. Hepatol. 38, 564-572.

(40) Kah, J., Wüstenberg, A., Keller, A. D., Sirma, H., Montalbano, R., Ocker, M., Volz, T., Dandri, M., Tiegs, G., and Sass, G. (2012) Selective induction of apoptosis by HMG-CoA reductase inhibitors in hepatoma cells and dependence on p53 expression. Oncol.Rep. $28,1077-1083$

(41) Zhu, Y., Casey, P. J., Kumar, A. P., and Pervaiz, S. (2013) Deciphering the signaling networks underlying simvastatin-induced apoptosis in human cancer cells: evidence for noncanonical activation of RhoA and Rac1 GTPases. Cell Death Dis 4, e568.

(42) Marcelli, M., Cunningham, G. R., Haidacher, S. J., Padayatty, S. J., Sturgis, L., Kagan, C., and Denner, L. (1998) Caspase-7 is activated during lovastatin-induced apoptosis of the prostate cancer cell line LNCaP. Cancer Res. 58, 76-83.

(43) Wu, J., Wong, W. W.-L., Khosravi, F., Minden, M. D., and Penn, L. Z. (2004) Blocking the Raf/MEK/ERK pathway sensitizes acute myelogenous leukemia cells to lovastatin-induced apoptosis. Cancer Res. 64, 6461-6468.

(44) Aprigliano, I., Dudas, J., Ramadori, G., and Saile, B. (2008) Atorvastatin induces apoptosis by a caspase-9-dependent pathway: an in vitro study on activated rat hepatic stellate cells. Liver Int. 28, 546-557. 
(45) Spampanato, C., De Maria, S., Sarnataro, M., Giordano, E., Zanfardino, M., Baiano, S., Cartenì, M., and Morelli, F. (2012) Simvastatin inhibits cancer cell growth by inducing apoptosis correlated to activation of Bax and down-regulation of BCL-2 gene expression. Int. J. Oncol. 40, 935-941.

(46) Gao, J., Jia, W.-D., Li, J.-S., Wang, W., Xu, G.-L., Ma, J.-L., Ge, Y.-S., Yu, J.-H., Ren, W.-H., Liu, W.-B., and Zhang, C.-H. (2010) Combined inhibitory effects of celecoxib and fluvastatin on the growth of human hepatocellular carcinoma xenografts in nude mice. J. Int. Med.Res. 38, 1413-1427.

(47) Weis, M., Heeschen, C., Glassford, A. J., and Cooke, J. P. (2002) Statins have biphasic effects on angiogenesis. Circulation 105, 739-745.

(48) Bayat, N., Izadpanah, R., Ebrahimi-Barough, S., Norouzi Javidan, A., Ai, A., Mokhtari Ardakan, M. M., Saberi, H., and Ai, J. (2018) The Anti-Angiogenic Effect of Atorvastatin in Glioblastoma Spheroids Tumor Cultured in Fibrin Gel: in 3D in Vitro Model. Asian Pac. J. Cancer Prev. 19, 2553-2560.

(49) Park, H.-J., Kong, D., Iruela-Arispe, L., Begley, U., Tang, D., and Galper, J. B. (2002) 3-hydroxy-3-methylglutaryl coenzyme A reductase inhibitors interfere with angiogenesis by inhibiting the geranylgeranylation of RhoA. Circ. Res. 91, 143-150.

(50) Relja, B., Meder, F., Wang, M., Blaheta, R., Henrich, D., Marzi, I., and Lehnert, M. (2011) Simvastatin modulates the adhesion and growth of hepatocellular carcinoma cells via decrease of integrin expression and ROCK. Int. J. Oncol. 38, 879-885.

(51) Ye, J., Wang, C., Sumpter, R., Brown, M. S., Goldstein, J. L., and Gale, M. (2003) Disruption of hepatitis $\mathrm{C}$ virus RNA replication through inhibition of host protein geranylgeranylation. Proc. Natl. Acad. Sci. U.S.A. 100, 15865-15870. 
(52) Lee, M.-H., Cho, Y. S., and Han, Y.-M. (2007) Simvastatin suppresses self-renewal of mouse embryonic stem cells by inhibiting RhoA geranylgeranylation. Stem Cells 25, 16541663.

(53) Cao, Z., Fan-Minogue, H., Bellovin, D. I., Yevtodiyenko, A., Arzeno, J., Yang, Q., Gambhir, S. S., and Felsher, D. W. (2011) MYC phosphorylation, activation, and tumorigenic potential in hepatocellular carcinoma are regulated by HMG-CoA reductase. Cancer Res. 71, $2286-2297$.

(54) Tatsuta, M., Iishi, H., Baba, M., Iseki, K., Yano, H., Uehara, H., Yamamoto, R., and Nakaizumi, A. (1998) Suppression by pravastatin, an inhibitor of p21ras isoprenylation, of hepatocarcinogenesis induced by $\mathrm{N}$-nitrosomorpholine in Sprague-Dawley rats. Br. J. Cancer $77,581-587$.

(55) Hwang, K.-E., Na, K.-S., Park, D.-S., Choi, K.-H., Kim, B.-R., Shim, H., Jeong, E.-T., and Kim, H.-R. (2011) Apoptotic induction by simvastatin in human lung cancer A549 cells via Akt signaling dependent down-regulation of survivin. Invest New Drugs 29, 945-952.

(56) Shibata, M.-A., Kavanaugh, C., Shibata, E., Abe, H., Nguyen, P., Otsuki, Y., Trepel, J. B., and Green, J. E. (2003) Comparative effects of lovastatin on mammary and prostate oncogenesis in transgenic mouse models. Carcinogenesis 24, 453-459.

(57) Vincent, L., Chen, W., Hong, L., Mirshahi, F., Mishal, Z., Mirshahi-Khorassani, T., Vannier, J. P., Soria, J., and Soria, C. (2001) Inhibition of endothelial cell migration by cerivastatin, an HMG-CoA reductase inhibitor: contribution to its anti-angiogenic effect. FEBS Lett. 495, 159-166. 
(58) Zheng, Y.-X., Zhou, P.-C., Zhou, R.-R., and Fan, X.-G. (2017) The benefit of statins in chronic hepatitis C patients: a systematic review and meta-analysis. Eur J Gastroenterol Hepatol 29, 759-766.

(59) Zhu, Q., Li, N., Han, Q., Zhang, P., Yang, C., Zeng, X., Chen, Y., Lv, Y., Liu, X., and Liu, Z. (2013) Statin therapy improves response to interferon alfa and ribavirin in chronic hepatitis C: a systematic review and meta-analysis. Antiviral Res. 98, 373-379.

(60) McGlynn, K. A., Hagberg, K., Chen, J., Graubard, B. I., London, W. T., Jick, S., and Sahasrabuddhe, V. V. (2015) Statin use and risk of primary liver cancer in the Clinical Practice Research Datalink. J. Natl. Cancer Inst. 107.

(61) Kawaguchi, Y., and Mizuta, T. (2014) Interaction between hepatitis C virus and metabolic factors. World J. Gastroenterol. 20, 2888-2901.

(62) Assmus, B., Urbich, C., Aicher, A., Hofmann, W. K., Haendeler, J., Rössig, L., Spyridopoulos, I., Zeiher, A. M., and Dimmeler, S. (2003) HMG-CoA reductase inhibitors reduce senescence and increase proliferation of endothelial progenitor cells via regulation of cell cycle regulatory genes. Circ. Res. 92, 1049-1055.

(63) Shachaf, C. M., Kopelman, A. M., Arvanitis, C., Karlsson, A., Beer, S., Mandl, S., Bachmann, M. H., Borowsky, A. D., Ruebner, B., Cardiff, R. D., Yang, Q., Bishop, J. M., Contag, C. H., and Felsher, D. W. (2004) MYC inactivation uncovers pluripotent differentiation and tumour dormancy in hepatocellular cancer. Nature 431, 1112-1117.

(64) Zheng, X., Cui, X.-X., Gao, Z., Zhao, Y., Lin, Y., Shih, W. J., Huang, M.-T., Liu, Y., Rabson, A., Reddy, B., Yang, C. S., and Conney, A. H. (2010) Atorvastatin and celecoxib in combination inhibits the progression of androgen-dependent LNCaP xenograft prostate tumors to androgen independence. Cancer Prev Res (Phila) 3, 114-124. 
(65) Ward, N. C., Watts, G. F., and Eckel, R. H. (2019) Statin Toxicity. Circ. Res. 124, 328350.

(66) Backes, J. M., Ruisinger, J. F., Gibson, C. A., and Moriarty, P. M. (2017) Statinassociated muscle symptoms-Managing the highly intolerant. J Clin Lipidol 11, 24-33.

(67) Sirvent, P., Bordenave, S., Vermaelen, M., Roels, B., Vassort, G., Mercier, J., Raynaud, E., and Lacampagne, A. (2005) Simvastatin induces impairment in skeletal muscle while heart is protected. Biochem. Biophys. Res. Commun. 338, 1426-1434.

(68) Silva, M., Matthews, M. L., Jarvis, C., Nolan, N. M., Belliveau, P., Malloy, M., and Gandhi, P. (2007) Meta-analysis of drug-induced adverse events associated with intensivedose statin therapy. Clin Ther 29, 253-260.

(69) de Denus, S., Spinler, S. A., Miller, K., and Peterson, A. M. (2004) Statins and liver toxicity: a meta-analysis. Pharmacotherapy $24,584-591$.

(70) Kubatka, P., Kruzliak, P., Rotrekl, V., Jelinkova, S., and Mladosievicova, B. (2014) Statins in oncological research: from experimental studies to clinical practice. Crit. Rev. Oncol. Hematol. 92, 296-311. 
For Table of Contents Only

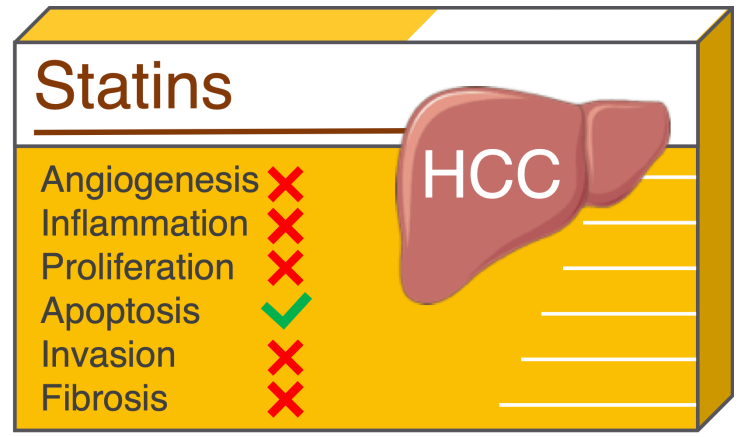

